\title{
28 Research Square \\ Climate Zoning Under Climate Change Scenarios In The Basin Of Lake Urmia And Vicinity Basins
}

\section{Rasoul Jani}

Islamic Azad University

Rahman Khatibi ( $\nabla$ gtev.rex@gmail.com )

GTEV-ReX Limited https://orcid.org/0000-0002-5490-1459

\section{Sina Sadeghfam}

University of Maragheh https://orcid.org/0000-0002-9018-547X

Elnaz Zarrinbal

Islamic Azad University

\section{Research Article}

Keywords: Climate Modelling and Zoning, Climate Scenarios, Lake Urmia Basin, Lars-WG, Planning and Policymaking

Posted Date: January 11th, 2022

DOI: https://doi.org/10.21203/rs.3.rs-1187656/v1

License: () (1) This work is licensed under a Creative Commons Attribution 4.0 International License. Read Full License 


\section{Abstract}

A study of climate change scenarios is presented in this paper by projecting a set of recorded precipitation data into three future periods by statistical downscaling methods by employing LARS-WG using data from 7 synoptic stations. The study area covers the basin of Lake Urmia and its overlaps with two of its surrounding basins flowing to the Caspian Sea. The modelling is at two stages: Downscaling comprises: (i) use large-scale GCM models to provide climate variables (predictors); and (ii) downscale them to the local climatic variables for correlating with the observed timeseries (e.g. rainfall) for the period of T0: 1961-2001 - 40 years; Projecting comprises the derivation of precipitation values during the time periods of ; T1: 2011-2030), T2: 2046-2065 and T3: 2080-2099 at synoptic stations using three of standard scenarios: A1B, A2 and B1. These values are then used to map the climate zoning, which show: (i) climates at T1 are still similar to T0 and if any difference, precipitation increases; but changes are likely at T2 and T3 periods; (ii) the climate is moving toward a peakier regime at the northern region but drier towards the central region; and (iii) precipitation is likely to decrease in some of the zones. Thus, the results underpin the need for more responsive policymaking and should this not be realised in the next 5 to 10 years, the future seems bleak, as the loss of Lake Urmia and the depletion of aquifers are likely to be permanent, inflicting immigration from the region.

\section{Introduction}

The distressed state of Lake Urmia, quite publicised even at the international scale, has been attributed to climate change by some researchers but not all, and as such the message is mixed and confusing. Whilst scientific evidence for climate change is overwhelming, it is a process that has kicked off and inflicts its initial impacts, but not necessarily a singular agent of disaster yet. The substantial amount of shrinkage of Lake Urmia took place in the living memory between 1990-2006, during which nearly 40 dams were constructed in this small basin, and this alone should be the first candidate for its shrinkage rather than climate change. An investigation is therefore presented here to examine potential trends in the region with respect to the availability of the amount of water. The focus of the paper is the projection of existing precipitation data towards the future by presenting the results of a LARS-WG model to gain an insight into the future conditions. The emerging insight from climate change modelling will touch on the depletion of groundwater aquifers, and the role of policymaking.

The paper uses the science of climate change to study climatic zoning of the basin of Lake Urmia and of some of the overlapping basin through a best practice modelling study, which delineates the zones within different spatiotemporal resolutions. The climate of each region is characterised by climatic indicators, e.g. De Martonne Drought Index (MI), calculated by annual precipitation and temperature for each synoptic recording station. The science of climate change is now quite wellestablished, which projects through the data over the years into the future by using scenarios to study dynamic processes of the Earth and external factors such as changes in the intensity of solar radiation or human activities. The external climate factors, known as climatic forcing, include variations in solar radiation, deviation in the movement of the earth and greenhouse gases. Using climatic forcings and patterns of anthropogenic activities in the form of scenarios, adverse impacts are studied with a potential to detect the likelihood of undermining the integrity of the ecological and social wellbeing at a study area. The paper uses three of these scenarios to investigate possible future impacts, which comprise A1B: a balanced emphasis on all energy sources; A2: a world more divided, but more ecologically friendly; B1: a world more integrated, and more ecologically friendly.

The detection of climate change is not limited to climate zoning but signals can be detected through timeseries analysis of the recorded data on radiation, temperature, precipitation, stream flows, evaporation and other hydrometeorological variables. Various studies, to be outlined in the review of literature in the next section, seem to reflect conflicting outcomes for the basin of Lake Urmia, as some detect signals but others do not. A critical view is necessary on conflicting results for the Lake Urmia basin, to stimulate the debate on the need for the overdue decisions on saving Lake Urmia. The challenge is that the reporting of scientific studies on climate change should not be limited to presenting the results alone but Khatibi (2022) argues that the scientific and modelling results should be presented with reference to policy and decision-making practices. Thus, the paper outlines a cursory overviews of these details. 
The overwhelming international evidence for climate change is the driver for this topical research into the risk of climate change in the basin of Lake Urmia, to provide the basis to learn, among other things, local impacts to underpin mitigation strategies. The paper uses LARS-WG, as one of the industry-norm software applications, to climate zoning of the study area. It uses local data and estimates correlations between local and global data for generating future weather data under climate change condition. LARS-WG is used widely, which randomises weather data generation models and is capable of generating daily precipitation, radiation, maximum and minimum daily temperatures in a synoptic weather station under current and future climate conditions.

For studies on Lake Urmia and its basin, the perception of decisionmakers on climate change seems to serve as a pretext for no action as 'climate change' is used to justify the drying of Lake Urmia. Any reference to climate change, at least in the context of the basin of Lake Urmia, needs to provide evidence if the process has reached a detectably biting point but the paper examine the subject with no presumptions, one way or another.

\section{Review Of Past Studies On Climate Change For The Urmia Basin}

The basin of Lake Urmia covers large proportions of East and West Azerbaijan provinces in northwest Iran and is located in a geographical position near Turkey. The lake is located just $150 \mathrm{~km}$ to the east of Lake Van in Turkey and a comparison of their water levels is given in Fig. 1. The figure shows a striking similarity until the year 2000 but a drastic decline in the water levels of Lake Urmia since then. Climatic studies in both countries are therefore relevant to a better understanding of the study area, which covers the basin and its overlaps with its surrounding catchments (two basins of Araz at the north of the basin of Lake Urmia). Some of the past studies related to the basin of Lake Urmia are presented in Table 1.

Table 1: Published refereed papers on climate change related to the basin of Lake Urmia 


\begin{tabular}{|c|c|c|c|c|}
\hline $\begin{array}{l}\text { Refereed } \\
\text { Paper }\end{array}$ & $\begin{array}{l}\text { Scope (river, or } \\
\text { sub-basin } \\
\text { basin) }\end{array}$ & Length of Data & Methods & $\begin{array}{l}\text { Trend } \\
\text { detection } \\
(\mathrm{Y} / \mathrm{N})\end{array}$ \\
\hline \multirow{2}{*}{$\begin{array}{l}\text { Abbaspour } \\
\text { et al } \\
(2009)\end{array}$} & \multirow{2}{*}{$\begin{array}{l}37 \text { climate } \\
\text { stations } \\
\text { across the } \\
\text { country }\end{array}$} & 22 Yr (1980-2002) & \multirow{2}{*}{$\begin{array}{l}\text { Canadian Global Coupled } \\
\text { downscaling and SWAT model }\end{array}$} & \multirow{2}{*}{$\begin{array}{l}\text { Yes: trend } \\
\text { is } \\
\text { detected }\end{array}$} \\
\hline & & Discharges and rainfall & & \\
\hline $\begin{array}{l}\text { Alizade } \\
\text { Govarchin } \\
\text { Ghale et al. } \\
(2017)\end{array}$ & $\begin{array}{l}\text { Lake Urmia } \\
\text { Basin }\end{array}$ & $\begin{array}{l}40 \text { Yr (1975-2016); on salt, } \\
\text { salty soil, waterbodies }\end{array}$ & remote sensing techniques & No \\
\hline \multirow{2}{*}{$\begin{array}{l}\text { Azizzadeh, } \\
\text { and Javan } \\
(2018)\end{array}$} & \multirow{2}{*}{$\begin{array}{l}\text { Lake Urmia } \\
\text { basin }\end{array}$} & 27 Yr(1987-2014) & \multirow[t]{2}{*}{ Mann-Kendall test } & \multirow{2}{*}{$\begin{array}{l}\text { Yes: trend } \\
\text { is } \\
\text { detected }\end{array}$} \\
\hline & & Temperature & & \\
\hline $\begin{array}{l}\text { Sanikhani, et } \\
\text { al. (2018) }\end{array}$ & $\begin{array}{l}\text { Urmia Basin: } \\
\text { Aji-Chay and } \\
\text { Mahabad- } \\
\text { Chay River } \\
\text { basins }\end{array}$ & $\begin{array}{l}\text { rainfall, solar radiation, } \\
T_{\min }, T_{\max } \text {. and runoff }\end{array}$ & $\begin{array}{l}\text { LARS-WG for downscaling and } \\
\text { gene expression programming (GEP) for } \\
\text { simulating runoff }\end{array}$ & $\begin{array}{l}\text { Yes: trend } \\
\text { is } \\
\text { detected }\end{array}$ \\
\hline $\begin{array}{l}\text { Zamani } \\
\text { Nuri, et al. } \\
\text { (2013) }\end{array}$ & $\begin{array}{l}\text { Lake Urmia } \\
\text { basin }\end{array}$ & $\begin{array}{l}\text { Rainfall, temperatures, De } \\
\text { Martonne index }\end{array}$ & new methodology and spatial downscaling & $\begin{array}{l}\text { Yes: trend } \\
\text { is } \\
\text { detected }\end{array}$ \\
\hline $\begin{array}{l}\text { Hosseini- } \\
\text { Moghari et } \\
\text { al (2018) }\end{array}$ & $\begin{array}{l}\text { Lake Urmia } \\
\text { basin }\end{array}$ & $\begin{array}{l}10 \mathrm{Yr}(2003-2013) \text { data, } \\
\text { the loss of lake water } \\
\text { volume and of GW; total } \\
\text { water storage in the entire } \\
\text { Lake Urmia basin }\end{array}$ & WaterGAP Global Hydrology Model (WGHM) & $\begin{array}{l}\text { No trend } \\
\text { is } \\
\text { detected }\end{array}$ \\
\hline \multirow{2}{*}{$\begin{array}{l}\text { - Delju, et } \\
\text { al (2012) }\end{array}$} & \multirow{2}{*}{$\begin{array}{l}\text { Lake Urmia } \\
\text { Basin }\end{array}$} & $40-\operatorname{Yr}(1964-2005)$ & \multirow{2}{*}{$\begin{array}{l}\text { Kruskal-Wallis method; Palmer Drought } \\
\text { Severity Index; Emberger classification; } \\
\text { Thornthwaite's method (water balance); } \\
\text { Mann-Kendall rank correlation test }\end{array}$} & \multirow{2}{*}{$\begin{array}{l}\text { Result } \\
\text { related to } \\
\text { CC }\end{array}$} \\
\hline & & $\begin{array}{l}\text { mean monthly temperature } \\
\text { and precipitation data }\end{array}$ & & \\
\hline $\begin{array}{l}\text { M. Ahmadi } \\
\text { Jamal, M. } \\
\text { Hasanlou } \\
(2017)\end{array}$ & Lake Urmia & $\begin{array}{l}6 \text { Yr (2010-16) - daily } \\
\text { hydrological data: } \\
\text { precipitation, surface } \\
\text { evaporation \& discharge }\end{array}$ & $\begin{array}{l}\text { polynomial regression technique combining } \\
\text { polynomial with periodic behaviour }\end{array}$ & $\begin{array}{l}\text { No trend } \\
\text { is } \\
\text { detected }\end{array}$ \\
\hline $\begin{array}{l}\text { Hatami \& } \\
\text { Dariane } \\
\text { (2015) }\end{array}$ & $\begin{array}{l}19 \text { stations of } \\
\text { Lake Urmia }\end{array}$ & $\begin{array}{l}40-Y r \text { Temperature and } \\
\text { water levels }\end{array}$ & Mann-Kendall-non parametric tests & $\begin{array}{l}\text { No trend } \\
\text { is } \\
\text { detected }\end{array}$ \\
\hline $\begin{array}{l}\text { Ghorbani et } \\
\text { al. (2018) }\end{array}$ & $\begin{array}{l}\text { Upper Jighati } \\
\text { River }\end{array}$ & 40-Yr Stream Flow & $\begin{array}{l}\text { Detecting signals from records used in } \\
\text { modelling river levels using Inclusive } \\
\text { Multiple Models }\end{array}$ & $\begin{array}{l}\text { No trend } \\
\text { is } \\
\text { detected }\end{array}$ \\
\hline $\begin{array}{l}\text { Jalili et al } \\
\text { (2016) }\end{array}$ & $\begin{array}{l}\text { Lakes Urmia } \\
\text { and Van }\end{array}$ & $\begin{array}{l}\text { Urmia data (1966-2014 for } \\
\text { Urmia),(1944-2014 for Van) } \\
\text { water Level }\end{array}$ & $\begin{array}{l}\text { Sequential test analysis of regime shifts } \\
\text { (Stars Method) and the Mann-Kendall test } \\
\text { and Coherency analysis }\end{array}$ & $\begin{array}{l}\text { No trend } \\
\text { is } \\
\text { detected }\end{array}$ \\
\hline $\begin{array}{l}\text { Alborzi et al. } \\
\text { (2018) }\end{array}$ & $\begin{array}{l}\text { Urmia Lake } \\
\text { Basin }\end{array}$ & water level ecological level & $\begin{array}{l}\text { A generalized river basin decision support } \\
\text { system model of flow networks }\end{array}$ & $\begin{array}{l}\text { No trend } \\
\text { detected }\end{array}$ \\
\hline \multirow{2}{*}{$\begin{array}{l}\text { P. Razmara } \\
\text { and et al } \\
\text { (2013) }\end{array}$} & \multirow{2}{*}{$\begin{array}{l}\text { Lake Urmia } \\
\text { basin }\end{array}$} & 30 Yr (1960-1990) & \multirow{2}{*}{$\begin{array}{l}\text { Modelled change-factor of LARS } \\
\text { downscaling-runoff rainfall of the region by } \\
\text { ANN and uncertainty of climate variability } \\
\text { by Beta function }\end{array}$} & \multirow{2}{*}{$\begin{array}{l}\text { Yes: trend } \\
\text { is } \\
\text { detected }\end{array}$} \\
\hline & & Temperature and Rainfall & & \\
\hline $\begin{array}{l}\text { Khatibi et al } \\
(2020)\end{array}$ & $\begin{array}{l}\text { Lakes Urmia } \\
\text { and Van }\end{array}$ & $\begin{array}{l}\text { Water level: Urmia: } 40 \text { Yr; } \\
\text { Van: Yr }\end{array}$ & $\begin{array}{l}\text { One objective was to search fo trends in the } \\
\text { reesiduals of predictive models }\end{array}$ & $\begin{array}{l}\text { No trend } \\
\text { is }\end{array}$ \\
\hline
\end{tabular}

Page 4/20 
The various directions of research concerning the study area include: climate change studies; trends in streamflows of the watercourses flowing to the lake as well as those of other hydrological variables; and prediction of water levels of the lake. These are reviewed for the study area with a focus on Lake Urmia and outlined for Lake Van. A study of trends in various hydrological variables may or may not detect any trend. The paper is not critically reviewing these published papers but is focussed on attributing any trend to climate change, arguing that this should be with caution of not encouraging no action to the restoration of Lake Urmia.

\subsection{Climate Change Studies}

The authors are not aware of any systematic study on the baseline for climate patterns prior to 1990 related to the basin of Lake Urmia. A study of climate change in Iran by Amiri and Eslamian (2010) is indicative of increases in the average temperature in Iran by 2100 in the range of $1.5^{\circ} \mathrm{C}-4.5^{\circ} \mathrm{C}$ if the $\mathrm{CO}_{2}$ concentration doubles by then, which is capable of significant impacts on water resources. Abbaspour et al (2009) investigated impacts of climate change on water resources in Iran using the SWAT model by generating future conditions under three scenarios A1B, A1 and B2. They found that in general, wet regions of the country will likely receive more rain while those in dry regions will be likely to receive less. Sadeghfam et al (2021) studied impacts of climate change on precipitation in Gilan province in Iran but considered the neighbouring meteorological data from Ardabil province using the SDSM software. They aimed to improve the robustness of their downscaling model by using Inclusive Multiple Modelling (IMM) practices, as discussed by Khatibi and Nadiri (2020) and Khatibi et al (2020). Their projected results indicate a likely reduction in precipitation around Ardabil province in the future. Notably, Ardabil province is also included in the study presented in the paper and this provides an opportunity to corroborate the respective results.

Systematic studies on baseline and recent climatic changes in Turkey are outlined by various studies. One study (see https://www.climatechangepost.com/turkey/climate-change/) outlines climate change impacts on precipitation as follows. In general, precipitation decreases in the T3 period with respect to T0 (1961-1990) along the Aegean and Mediterranean coasts and increases along the Black Sea coast of Turkey. Central Anatolia shows little or no change in precipitation. The most severe (absolute) reductions will be observed on the southwestern coast; in contrast, the Caucasian coastal region is likely to receive substantially more precipitation. These observations are valid both for the annual and the winter totals, according to which different climate change scenarios are likely to inflict a decrease of $5 \%$ in mean annual precipitation by 2030 . In 2050 , mean annual precipitation is likely to decrease by approximately $10 \%$. Decreases are likely in precipitation in all months with sharp decreases in spring and autumn, because summers in the region are already dry.

Ahmadaali et al (2017) evaluate the indices of environmental and agriculture sustainability using performance criteria influenced by climate change and water management strategies for the River Cighati (zarrinehrud) and River Tatovu (siminehrud) basins, the largest basins in the basin of Lake Urmia. Their results are indicative of highest values of indices of environmental and agricultural sustainability to stem from the scenario of combining the crop pattern change with improving the total irrigation efficiency under the B1 emission scenario (B1S4). Razmara et al (2013) study the effect of climate change on the runoff entering Lake Urmia using AOGCM-AR4 models with 2 scenarios (A2 and B1) for T1(2013-2040 years) and report a decrease in streamflow into the lake in scenario $A 2$ at the risk levels of $25 \%, 50 \%$ and $75 \%$ with reductions of $-21 \%,-13 \%$ and $-0.3 \%$, respective; and an increase by $4.7 \% 13.8 \%$ and $18.9 \%$ in scenario $\mathrm{B} 1$, respectively.

\subsection{Trend Studies in Various Hydrological Variables}

A study of trends in various hydrological variables related to the basin of Lake Urmia is topical, some of which are outlined in Table 1. More often than not, no trend is detected, which may be explained by the length of the duration of the available data. Their interpretations are of paramount importance, as they do not explain in any way the disaster of the drying of Lake Urmia 
in the living memory, although they often fail to call for a planning system to underpin and the absence of which the likely explanation for the ongoing problems and lead the way for a planning system to cater for incremental adaptations towards 2100.

Stream flows in the basin of Lake Urmia have been studied by various researchers including that by Ghorbani et al. (2018). They use a modelling strategy based on Inclusive Multiple Models (IMM) practices and formulate multiple models at two levels to enhance robustness and thereby ensure that the information content within the models are not impacted by modelling errors. In this way, they do not detect any trend in the error residuals. Similarly, Khatibi et al. (2020) formulated modelling strategies based on IMM practices and studied water level time series of Lake Urmia and Lake Van but do not detect any trend signals in the error residuals. Both acknowledge the importance of climate change but rule out the role of climate change on the Lake Urmia disaster, which is readily attributable to mismanagement since 1995.

A study of the water balance in Lake Urmia in conjunction with the surrounding aquifers and surface water inflows is described by Vahedoost and Aksoy (2021). They conclude that groundwater and evaporation are significant variables on the decline in the water level of Lake Urmia but the effect of groundwater surpasses all other variables. Arguably, the decline should not be attributed to droughts as prolonged droughts are rare in the region, but those sensed ones are often operational during peak demands. Sadeghfam et al (2018) studied risks of drought in the Maragheh-Bonab aquifer, located at the southwest bank of Lake Urmia. They concluded that groundwater drought are mainly affected by groundwater over-abstraction rather than deficit in precipitation. Also, the spatial distribution of groundwater drought risk is more critical in the direction from the upper catchments toward its lower reaches near Lake Urmia.

\subsection{Lake Water Levels}

Khatibi et al. (2020) refer to the plethora of predictive models of water levels of Lake Urmia driven by research interests and argues that these models serve very little practical purpose, as the lake has no navigation value in its present state and no water resources value for being a salt lake. Further reviews of the vast volume of research on predicting water level of Lake Urmia are not therefore reviewed here.

\subsection{Overview of the Reviews}

The above conflicting results are natural and expected. These all underpin the need for management plans and action plans to put in place incremental actions. However, no such plans are yet accessible to public if they ever exit. Instead, climate change is used as a pretext for no action but it should underpin the need for preparation to the impacts.

\section{Methodology By Using Downscaling Tools}

The paper uses LARS-WG as a statistical downscaling technique to project daily precipitation and temperature under different scenarios into three future periods based on statistical characteristics of the variables. The projection results are represented by using De Martonne Index (DMI) to gain a deeper insight into the climate variability within the study area.

\subsection{The Modelling Strategy}

The objective in this study is to gain a basic insight into possible climate change patterns in the future within the Lake Urmia basin and its overlapping catchments. The overall approach is based on using one of the industry-norm models, e.g. LARSWG, SDSM or CLIGEN. The paper uses LARS-WG in two stages: downscaling and projection as follows.

At the first stage, the process of downscaling by LARS-WG comprises: (i) use large-scale GCM climate variables, referred to as predictors, which are a large set of variables but they are internally screened by LARS-WG; and (ii) statistically downscale the 
selected predictors to the local climatic variable of observed data at daily timescale referred to as predictand (e.g. rainfall, sunshine hours or temperatures), which are observed for a reasonable length of time at one or more synoptic stations. LARSWG provides tools to establish relationships between the GCM predictors and local scale predictand. Various metrics are available to test the goodness of fit, e.g. the $T$ and $F$ tests.

At the second stage, LARS-WG models are used to project future values of predictands (projected precipitation and temperature) under the following selection of climate change scenarios: A1B: a balanced emphasis on all energy sources; A2: a world more divided, but more ecologically friendly; and B1: a world more integrated, and more ecologically friendly. The projections are normally carried out for the three periods of 20-year: (i) the first period (T1: 2011-2030), the second period (T2: 2046-2065) and the third period (T3: 2080-2099).

Although projections are at daily or monthly intervals, due to high uncertainties associated with the future values, a normal practice is to average the values at each month of the 'average year' for each period. For example, the values during T3 comprise a hydrograph from 2080 to 2099 but they are presented in the form of 12 values, one value per month from January to December and each value is the mean of their corresponding value for 20 years from 2080 to 2099.

The projected values are then used to assess possible climatic zoning for the synoptic station. One such technique is the De Martonne index and the comparison of observed and generated zoning provides an indication towards possible patterns of climate change at the synoptic station. These are described below.

\subsection{The LARS-WG Model}

LARS-WG is a statistical downscaling model, which seeks the establishment of a relationship between large-scale predictors and local predictand. It is also a weather generator to produce statistical models from observed sequences of weather variables by using complex random number generators. Their inputs comprise a set of large-scale predictors and outputs include daily weather data at a particular location as a predictand. It has a capability to produce semi-empirical weather generator to approximate probability distributions of dry and wet series, daily rainfall, minimum and maximum temperatures and solar radiation, based on a series that may be used in simulating meteorological data in an individual station (Semenov et al., 1998; Semenov and Brooks, 1999; Racsko et al., 1991). The capability is also used to study the present and future climatic conditions.

For any climate variable $V$, the value of the $V_{i}$, corresponding to the probability $P_{i}$, is calculated through the following equation:

$$
V_{i}=\min \left\{V: P\left(V_{o b s} \leq V\right) \geq P_{i}\right\} \quad i=0, \ldots, n
$$

where probability in terms of the data observed or $V_{\text {obs. }}$. For any climatic variables, the $P_{o}$ and $P_{n}$ are equal to 0 and 1 respectively; they are constant with the relevant $V_{n}=\max \left(V_{\text {obs }}\right)$ and $V_{o}=\min \left\{V_{\text {obs }}\right\}$ (Semenov and Stratonovitch, 2010).

\subsection{Study Area and the Data}

The study area, shown in Fig. 2, which comprises seven synoptic stations, each located within a city at three provinces of: (i) the province of Ardabil (using the stations at Ardabil and Parsabad), (ii) the East Azerbaijan province (using the stations at Ahar (Eher), Julfa and Tabriz), and (iii) the West Azerbaijan province (Khoy and Urmia ). These stations are located in northwest Iran with daily meteorological data, which cover the period from January 1961 to December 2001 (40 years), as provided by Iran Meteorological Organisation. Ideally, more data would have been appropriate at the southwest of the study area but were not available at the time of the study. Table 2 presents their statistical summary. Notably, LARS-DW capabilities has automatic facilities to deal with any missing data. 
Table 2. Statistical characteristics of meteorological site data (T0: January 1961 - December 2001)

\begin{tabular}{|llllll|}
\hline Station & $\begin{array}{l}\text { Maximum Daily } \\
\text { Temperature }\left({ }^{\circ} \mathrm{C}\right)\end{array}$ & $\begin{array}{l}\text { Minimum Daily } \\
\text { Temperature }\left({ }^{\circ} \mathrm{C}\right)\end{array}$ & $\begin{array}{l}\text { Max Daily } \\
\text { Precipitation }(\mathrm{mm})\end{array}$ & $\begin{array}{l}\text { Max Annually } \\
\text { Precipitation }(\mathrm{mm})\end{array}$ & $\begin{array}{l}\text { Dry } \\
\text { Days } \\
(\%)\end{array}$ \\
\hline Ahar & 40.0 & -27.5 & 47.0 & 494.5 & 81.0 \\
\hline Ardabil & 39.0 & -33.8 & 63.0 & 620.6 & 77.6 \\
\hline Julfa & 44.0 & -28.5 & 52.0 & 328.8 & 83.1 \\
\hline Khoy & 42.0 & -30.0 & 44.0 & 425.1 & 74.2 \\
\hline Parsabad & 42.6 & -16.5 & 65.4 & 449.5 & 81.3 \\
\hline Tabriz & 42.0 & -25.0 & 63.0 & 547.2 & 78.0 \\
\hline Urmia & 38.0 & -24.0 & 62.0 & 564.0 & 79.6 \\
\hline
\end{tabular}

\subsection{De Martonne Index}

The De Martonne Index (DMI) is used in this study to characterise the climate of each station. The index is calculated for every year in each station, then the average of these index values is obtained for each decade. DMI is calculated as follow:

$$
D M I=\frac{P}{T+10}
$$

where $P$ is the annual amount of precipitation $(\mathrm{mm})$ and $T$ is the mean annual air temperature $\left({ }^{\circ} \mathrm{C}\right)$. Generally, the climate types are characterised as per DMI ranges in Table 3, which also presents the values of DMI for each station during the years of 1991-2001. The values indicate that all stations are characterised as per arid and semi-arid climate zones.

Table 3. Different climate type as per DMI values

\begin{tabular}{|llll|}
\hline Types of Climate & DMI ranges & DMI at the Stations & DMI (1991-2001) \\
\hline Arid & $\mathrm{DMI}<10$ & Ardabil & 18.9 \\
\hline Semi-arid & $10<\mathrm{DMI}<20$ & Parsabad & 10.1 \\
\hline Mediterranean & $20<\mathrm{DMI}<24$ & Tabriz & 12.6 \\
\hline Semi-humid & $24<\mathrm{DMl}<28$ & Julfa & 6.1 \\
\hline Humid & $28<\mathrm{DMI}<35$ & Ahar & 11.5 \\
\hline Very humid & $35<\mathrm{DMI}<55$ & Urmia & 14.9 \\
\hline Extremely humid & $\mathrm{DMI}>55$ & Khoy & 11.4 \\
\hline Colour Code & Arid & Semi-arid & \\
\hline
\end{tabular}

\subsection{Performance Metrics}

In the downscaling phase, the LARS-WG model is calibrated by carrying out statistical tests. The study used the T and F tests, in which the $T$ test involves the testing of the means and the $F$ test that of the standard deviation. These test procedures are 
well-established in statistics and hydrological modelling and are not detailed here.

\subsection{Spatial Modelling}

Spatial modelling is used to interpolate the point data, such as observed precipitation, or modelled values, including DMI or mean precipitation, to gain an insight into their spatial distributions. There are various techniques available but the paper uses the Inverse Distance Weight (IDW) technique.

\section{Results}

In this research, climate change data for each synoptic station is investigated by LARS-WG for the following periods - T0: (1961-2001), T1: (2011-2030), T2: (2046-2065) and T3: (2080-2099) at two stages of downscaling and projection.

\subsection{Downscaling Results}

In the first stage of climate modelling by LARS-WG, the aim here is to develop a statistical downscaling model, which comprises the following step: (i) for a given synoptic station, LARS-WG obtains a daily large-scale set of GCM climate variables, normally referred to as 'predictors', which are processed through a number of internal steps, e.g. screening the predictors (LARS-WG caters for these processes automatically, so they are not described here); (ii) the daily precipitation and temperature data at the synoptic stations are further processed by the modeller by estimating the mean monthly precipitation and temperature over typical months within the T0 period, which are used as the dependent variable (referred to as predictand) in a regression equation; (iii) LARS-WG establishes multiple regression equations between predictands and predictors, one for each month of downscaling periods.

The results produced by LARS-WG for each station and each month of the T0 period are then analysed by the modeller. One set of downscaling results is shown in Fig. 3 for Tabriz station, which shows that there are distinct wet and dry periods. The figure compares downscaled precipitation values with their corresponding observed values for each month of the averaged year. Their visual intercomparison indicates that the modelled values by LARS-WG largely converge with the observed values but there are also deviations, which are analysed statistically in Table 4. The table gives the mean monthly precipitation averaged

over the observed period and their performance statistics and probabilities, all for the T0 period: (1961-2001). The probability values are also given in the table, according to which at the $5 \%$ level of significance, the LARS-WG results and observed data are derived from the same population. Also, the modelled results are acceptable in terms of their standard deviations at the significance level of $5 \%$ except for January and October.

statistical analysis of the results for the all the stations confirm that their means and standard deviations of the results and observed data are drawn from the same population.

Table 4. Comparison between observed and modelled rainfall values at Tabriz station 


\begin{tabular}{|c|c|c|c|c|c|c|c|c|c|c|c|c|c|}
\hline Month & & Jan & Feb & Mar & Apr & May & Jun & Jul & Aug & Sep & Oct & Nov & Dec \\
\hline \multirow[t]{4}{*}{ Mean } & $\begin{array}{l}\text { Mean Observed } \\
\text { P. }\end{array}$ & 22.8 & 22.3 & 42.9 & 50.2 & 43.9 & 17.2 & 4.3 & 3.9 & 8.3 & 26.1 & 28.3 & 25 \\
\hline & Mean Modelled P. & 27.1 & 20.7 & 50.1 & 56.9 & 44.8 & 19.8 & 4.1 & 3.4 & 11.4 & 26.8 & 26.9 & 24.9 \\
\hline & T-test & -0.76 & 0.41 & 0.86 & 0.99 & 0.13 & 0.53 & 0.12 & 0.26 & -0.07 & -0.1 & 0.27 & 0.01 \\
\hline & Probability & 0.45 & 0.69 & 0.39 & 0.33 & 0.90 & 0.60 & 0.91 & 0.79 & 0.29 & 0.92 & 0.79 & 0.99 \\
\hline \multirow{4}{*}{$\begin{array}{l}\text { St. } \\
\text { Dev. }\end{array}$} & Sdv. Observed P. & 12.9 & 13.6 & 23.0 & 26.3 & 25.4 & 17.7 & 6.9 & 6.7 & 10.2 & 28 & 20.9 & 24.6 \\
\hline & Sdv. Modelled P. & 2.01 & 15.7 & 24.0 & 21.6 & 30.0 & 19.3 & 6.8 & 5.0 & 12.1 & 16.3 & 14.3 & 18.4 \\
\hline & F-test & 2.65 & 1.34 & 1.89 & 1.47 & 1.39 & 1.17 & 1.022 & 1.67 & 1.45 & 2.96 & 2.11 & 1.79 \\
\hline & Probability & 0.01 & 0.43 & 0.14 & 0.36 & 0.37 & 0.64 & 1.00 & 0.18 & 0.31 & 0.01 & 0.08 & 0.17 \\
\hline
\end{tabular}

\subsection{Projection Results}

The downscaled results provide a relationship between the local downscaled predictands and the global-scale predictors for the T0 period. However, climate models provide the values of these predictors for T1, T2 and T3 periods, which are then used by the LARS-WG models to project local precipitation and temperature values onto T1, T2 and T3 periods, as a way to study climate change at local stations. The results presented in Table 5 summarise the projected climate results for all the synoptic stations. These comprise the results for the period T0: (1961-2001) and those for the projection periods of T1 to T3, as per Scenarios A1B, A2 and B1.

The results in Table 5 indicate that: (i) the maximum daily rainfall would occur in the first period (T1: 2011-2030) under Scenario A1; (ii) the maximum annual rainfall would occur in the first period (T1: 2011-2030) under Scenario B1; (iii) temperatures would increase over time (causing adverse impacts), according to which the highest temperature occurs in the third period (T3: 2080-2099) under Scenario A2; and (iv) the lowest temperature would occur in the second period (T2: 20652046) under Scenario B1.

Table 5 also give the full results and those for precipitation are displayed in Fig. 4 in terms of annual mean precipitations for each month of each period, each scenario and each station. These are further summarised in Fig. 5 in terms of total annual precipitation ratio (the ratio of (annual modelled precipitation - annual observed precipitation for the T0 period) divided to annual observed precipitation for the T0 period) for each scenario and each station, and each period of T1, T2, and T3. According to Figs. 4 and 5, the following salient features are evident: (i) the conditions in terms of precipitation during the T1 period are quite similar to those during the TO period for all most of the stations and if any difference, their precipitations are likely to be increasing except for a minor reduction at Ardabil and Julfa stations; (ii) for the T2 period, the climate change is likely to impact the region in terms of lesser amount of water availability but the amounts are likely to depend on the prevailing scenario, although the conditions at Khoy are likely to improve as well as a few other stations; (iii) during the T3 period, some scenarios are likely to impact less but others to impact in greater amounts and inflict as much as $25 \%$ loss of water availability; and (iv) most regions seem likely to remain within the same climate zone but the regions around Ardabil seems likely to suffer less water, as the temperature is likely to increase in the region.

The results in Fig. 5 provide a clear evidence that current situations designated as the T1 periods is much similar to the historic T0 periods and if anything, water availability is somewhat greater in terms of precipitation. Therefore, using climate change to explain the onset of the catastrophe of Lake Urmia cannot be justified on scientific grounds, although science is not fixed and more evidence needs to be gathered. 
Table 5 Comparison between climate variables for calibration and projection periods

Page $11 / 20$ 


\begin{tabular}{|c|c|c|c|c|c|c|c|c|c|c|}
\hline \multicolumn{11}{|l|}{ Ahar station } \\
\hline \multirow[t]{2}{*}{ Parameters } & Calibration & A1B & A1B & A1B & $\mathrm{A} 2$ & $\mathrm{~A} 2$ & $\mathrm{~A} 2$ & B1 & B1 & B1 \\
\hline & TO & T1 & T2 & T3 & $\mathrm{T} 1$ & T2 & T3 & T1 & T2 & T3 \\
\hline $\begin{array}{l}\text { Max Daily } \\
\text { Rainfall }\end{array}$ & 47 & 44.7 & 39.1 & 45.8 & 40.2 & 41.6 & 50.8 & 57.4 & 44.9 & 48.3 \\
\hline $\begin{array}{l}\text { Max Annual } \\
\text { rainfall }\end{array}$ & 494.5 & 501.2 & 451.7 & 461.6 & 492.6 & 492.8 & 394 & 506.1 & 477 & 449.1 \\
\hline $\begin{array}{l}\text { Max. Daily } T \\
-T_{\max }\end{array}$ & 40 & 40.8 & 43.3 & 45.2 & 40.8 & 43.2 & 46.3 & 41.2 & 42.2 & 43.5 \\
\hline $\begin{array}{l}\text { Min Daily } T \\
-T_{\text {Min }}\end{array}$ & -27.5 & -26 & -24.4 & -23.3 & -25.4 & -24.7 & -22.7 & -25.8 & -24.8 & -23.6 \\
\hline Dry Day (\%) & 81.02 & 82.21 & 82.10 & 82.13 & 82.98 & 82.97 & 82.94 & 82.98 & $82.21^{`}$ & 82.31 \\
\hline \multicolumn{11}{|c|}{ Ardabil station } \\
\hline $\begin{array}{l}\text { Max Daily } \\
\text { Rainfall }\end{array}$ & 63 & 47.8 & 42.7 & 46.4 & 65.1 & 45.4 & 44.6 & 50.3 & 44.5 & 44.7 \\
\hline $\begin{array}{l}\text { Max Annual } \\
\text { rainfall }\end{array}$ & 620.6 & 488.4 & 440.3 & 440.7 & 697.9 & 442.4 & 384.7 & 481 & 450.1 & 442.2 \\
\hline $\begin{array}{l}\text { Max. Daily } T \\
-T_{\max }\end{array}$ & 39 & 39.1 & 41.6 & 43.5 & 39.4 & 41.4 & 44.8 & 39.6 & 40.5 & 41.9 \\
\hline $\begin{array}{l}\text { Min Daily } T \\
-\mathrm{T}_{\text {Min }}\end{array}$ & -33.8 & -26.8 & -25 & -24 & -24.5 & -25.3 & -23.6 & -26.6 & -25.6 & -24.4 \\
\hline Dry Day (\%) & 77.99 & 79.55 & 81.3 & 81.4 & 80.24 & 80.95 & 81.26 & 80.93 & 80.76 & 81.36 \\
\hline \multicolumn{11}{|l|}{ Julfa station } \\
\hline $\begin{array}{l}\text { Max Daily } \\
\text { Rainfall }\end{array}$ & 52 & 30.2 & 27.3 & 31.5 & 29.7 & 31.4 & 26.9 & 31.5 & 34.8 & 25.6 \\
\hline $\begin{array}{l}\text { Max Annual } \\
\text { rainfall }\end{array}$ & 328.8 & 297.8 & 264.8 & 253 & 295.3 & 282.9 & 231.2 & 301.2 & 283.1 & 272.6 \\
\hline $\begin{array}{l}\text { Max. Daily } T \\
-T_{\max }\end{array}$ & 44 & 45.2 & 48.1 & 50.3 & 45.2 & 48.1 & 51.5 & 45.4 & 47.1 & 48.3 \\
\hline $\begin{array}{l}\text { Min Daily } T \\
-\mathrm{T}_{\text {Min }}\end{array}$ & -28.5 & -17 & -15.1 & -14 & -16.4 & -15.5 & -13.6 & -16.8 & -15.5 & -14.7 \\
\hline Dry Day (\%) & 83.14 & 84.04 & 83.98 & 83.98 & 84.04 & 83.98 & 83.78 & 84.04 & 84.02 & 83.98 \\
\hline \multicolumn{11}{|l|}{ Khoy station } \\
\hline $\begin{array}{l}\text { Max Daily } \\
\text { Rainfall }\end{array}$ & 44 & 40.8 & 39 & 43 & 45 & 40.2 & 41.3 & 44.8 & 45.1 & 37.5 \\
\hline $\begin{array}{l}\text { Max Annual } \\
\text { rainfall }\end{array}$ & 425.07 & 397.8 & 341.5 & 326.1 & 396.7 & 373.3 & 285 & 414.9 & 382.6 & 354.3 \\
\hline $\begin{array}{l}\text { Max. Daily } T \\
-T_{\max }\end{array}$ & 42 & 43.2 & 46.2 & 48.4 & 42.7 & 45.4 & 48.7 & 43 & 45 & 45.6 \\
\hline $\begin{array}{l}\text { Min Daily } T \\
-T_{\text {Min }}\end{array}$ & -30 & -25.2 & -23.2 & -22.1 & -27.4 & -26.3 & -24.4 & -28.5 & -26.4 & -25.3 \\
\hline Dry Day (\%) & 74.20 & 75.50 & 75.52 & 75.57 & 74.78 & 74.69 & 74.67 & 74.82 & 75.49 & 74.89 \\
\hline
\end{tabular}

Page $12 / 20$ 


\begin{tabular}{|c|c|c|c|c|c|c|c|c|c|c|}
\hline \multicolumn{11}{|c|}{ Parsabad station } \\
\hline $\begin{array}{l}\text { Max Daily } \\
\text { Rainfall }\end{array}$ & 65.4 & 62.5 & 43.2 & 41.4 & 64.4 & 61.9 & 51.3 & 59.8 & 50.3 & 59.3 \\
\hline $\begin{array}{l}\text { Max Annual } \\
\text { rainfall }\end{array}$ & 449.5 & 571.9 & 507.3 & 507.6 & 547.9 & 550.9 & 463.7 & 583.3 & 538.3 & 502.6 \\
\hline $\begin{array}{l}\text { Max. Daily } T \\
-T_{\max }\end{array}$ & 42.6 & 43.5 & 46.1 & 48.2 & 43.7 & 46.2 & 49.5 & 44 & 45 & 46.4 \\
\hline $\begin{array}{l}\text { Min Daily } T \\
-T_{\text {Min }}\end{array}$ & -16.5 & -14.7 & -12.2 & -9.4 & -14.1 & -13.5 & -11.5 & -14.6 & -12.5 & -12.2 \\
\hline Dry Day (\%) & 81.34 & 82.54 & 83.42 & 83.52 & 82.54 & 82.20 & 82.27 & 82.38 & 83.41 & 82.69 \\
\hline \multicolumn{11}{|l|}{ Tabriz station } \\
\hline $\begin{array}{l}\text { Max Daily } \\
\text { Rainfall }\end{array}$ & 63 & 63.5 & 42.6 & 53.9 & 63.1 & 60.2 & 50.1 & 60.9 & 42.5 & 58.8 \\
\hline $\begin{array}{l}\text { Max Annual } \\
\text { rainfall }\end{array}$ & 547.2 & 541.6 & 383.6 & 376.6 & 535.9 & 508.3 & 386.7 & 557.3 & 398.4 & 492.2 \\
\hline $\begin{array}{l}\text { Max. Daily } T \\
-T_{\text {max }}\end{array}$ & 42 & 41.3 & 44.1 & 46.2 & 41.4 & 44.1 & 47.5 & 41.6 & 43.2 & 44.3 \\
\hline $\begin{array}{l}\text { Min Daily } T \\
-T_{\text {Min }}\end{array}$ & -25 & -18.4 & -20.7 & -19.6 & -17.8 & -16.9 & -15 & -18.2 & -21.2 & -15.9 \\
\hline Dry Day (\%) & 77.99 & 78.0 & 78.5 & 78.5 & 78.0 & 78.0 & 78.0 & 78.0 & 78.5 & 78.1 \\
\hline \multicolumn{11}{|l|}{ Urmia station } \\
\hline $\begin{array}{l}\text { Max Daily } \\
\text { Rainfall }\end{array}$ & 62 & 76 & 72.3 & 61.8 & 69.2 & 69.8 & 57.8 & 76 & 68.2 & 66.2 \\
\hline $\begin{array}{l}\text { Max Annual } \\
\text { rainfall }\end{array}$ & 564 & 508.4 & 457.2 & 428.3 & 499.9 & 485.3 & 380.7 & 530.4 & 468.1 & 461.8 \\
\hline $\begin{array}{l}\text { Max. Daily } T \\
-T_{\max }\end{array}$ & 38 & 38.6 & 41.4 & 43.6 & 38.6 & 41.4 & 44.8 & 38.8 & 49.6 & 41.7 \\
\hline $\begin{array}{l}\text { Min Daily } T \\
-T_{\text {Min }}\end{array}$ & -24 & -22.8 & -20.8 & -19.8 & -22.2 & -21.3 & -19.4 & -22.7 & -21.5 & -20.4 \\
\hline Dry Day (\%) & 79.6 & 80.97 & 80.95 & 81.04 & 81.02 & 81 & 81 & 80.98 & 81 & 81 \\
\hline \multirow[t]{2}{*}{ Colour Code } & \multicolumn{2}{|c|}{ Increase in $T_{M a x}$} & \multicolumn{2}{|c|}{ Decrease in $T_{M a x}$} & \multicolumn{2}{|c|}{$\begin{array}{l}\text { Increase in } \\
\mathrm{P}_{\operatorname{Max}}\end{array}$} & \multicolumn{2}{|c|}{ Decrease in $\mathrm{P}_{\text {Max }}$} & \multicolumn{2}{|c|}{ Increased Dry Day } \\
\hline & \multicolumn{2}{|c|}{ Increase in $T_{M i n}$} & \multicolumn{2}{|c|}{ Decrease in $T_{\text {Min }}$} & \multicolumn{2}{|c|}{$\begin{array}{l}\text { Increase in } \\
\mathrm{P}_{\text {Min }}\end{array}$} & \multicolumn{2}{|c|}{ Decrease in $\mathrm{P}_{\mathrm{Min}}$} & \multicolumn{2}{|c|}{ Decreased Dry Day } \\
\hline
\end{tabular}

\subsection{Climate Zoning}

Whilst it is possible to study the results for each of the stations in the above manner, this would be an unwarranted belief into projected results in the foresight future. However, it is customary to study possible changes in the climate pattern, as explained by the De Martonne Index in Eq. (2). Therefore, the projected results at the synoptic stations are used to study the likely 
changes in the future climate patterns. Using the DMI values at each stage, they are also projected into the future for each period and for each scenario and their values are presented in Fig. 6. It shows that DMI in all the investigated meteorological stations increase when compared with those at the T0 period (1991-2001), except for Ardabil station in the first period (20112030). Thus, with the passing of time, the northwest zone is likely to be exposed to a greater risk of drought. In some scenarios, DMI is less than 10 , which indicates that the zone may change from semi-arid to arid climates.

The results in Fig. 6 show climate zoning for the T0, T1, T2 and T3 periods. As it may be seen from the figure, the climate in the study area is characterised by-and-large as semi-arid or arid under the T0 period, as well as under T1, T2 or T3 periods. There are marginal areas within the borders of each zone that are dependent on the scenario runs, which may undergo climatic changes. Otherwise, there does not seem to be any drastic sensitivity to climate change. These are discussed further in the next section.

\section{Discussion}

The results presented in the paper provide the basis to gain an oversight of the climate change within the basin of Lake Urmia and its vicinities. They conform with the international published data that during the onset of the catastrophe of Lake Urmia, the temperature was only $0.5^{\circ} \mathrm{C}$ to $1.0^{\circ} \mathrm{C}$ and currently it is $1.5^{\circ} \mathrm{C}$ to $1.6^{\circ} \mathrm{C}$, see CarbonBrief (2018). The paper in Fig. 5 shows clearly that precipitation during the $\mathrm{T} 1$ period corresponding to the present times is much like the period T0 corresponding to historic data available and if anything, more precipitation is being available now. On account of climate change results presented in the paper there is very little to explain any catastrophe or distress in the region. The large volume of literature on Lake Urmia attributing the problems to droughts or climate change are likely to be misguided. This is not to deny the importance of climate change in any way, but the results underpin the importance of climate change such that if the rights actions are not taken now, the future is likely to be bleak.

The study presented by the paper may be compared with a similar study by Sadeghfam et al (2021). They use the SDSM software and apply it to the recorded synoptic data at two grid cells, with the main cell at the south of the Caspian Sea in northwest Iran largely covering southern Gilan province and the second grid covers territories of East Azerbaijan, Ardabil and Zanjan provinces. A comparison between observed and projected precipitation results indicates that precipitation is likely to reduce in the projected periods in cold seasons (October to February), but the projected precipitation will be likely to increase slightly in wet season (April and May). Their reported behaviour is quite corroborated for the projected results in the paper with similar conclusion concerning Ardabil province.

There are various ways for more robust projections for the study as outlined next. A primary step is to incorporate more synoptic stations, particularly at the southwest of the study area. At the time of this study, no data were available to the authors, but this is currently being addressed for the future studies, which will go beyond the framework for the present study by investigating possible outliers and trends in the data. The GCM model runs serving the downscaling models in the paper were obtained automatically by LARS-WG. Another approach is to improve on the robustness of the downscaled result by using Inclusive Multiple Modelling (IMM) practices similar to Sadeghfam et al. (2021). Similarly, uncertainty studies can be applied to identify the sensitivities to the prominent parameters and measured data to identify possible climatic vulnerabilities and resilience but the authors are not aware of any such study for the study area.

The aquifers in the study area are at a serious risk of depletion. Broadscale published information on aquifers within the study area was reviewed as another source of information, (see: https://www.feow.org/ecoregions/interactive-map) to understand relative situation of the study area in its international context. These are outlined below: (i) the ecoregion designation of the basin of Lake Urmia is 446 with overlaps at ecoregions of 444 (Lake Van); and 434 (Araz); (ii) the percentage of areas equipped for irrigation at the study area is in the band of $10 \%-15 \%$ and this is a measure of potential adverse impacts on freshwater systems by abstracting water from natural systems and preventing or delaying its return through diversions and storage, the band is quite high globally and therefore the basin is at risk; (iii) the average human footprint in the basin is in the band of 20\%-30 and this band is in the medium range, which incorporates human access, land use with infrastructure, and population pressure; while greater human activities in a region are likely to lead to greater impacts on freshwaters; (iv) water 
use at the study area is indicated to be at the stressed band, where water stress is defined as the ratio of water use (i.e., surface water withdrawn for domestic, agriculture and livestock use) to water availability (the discharge by subbasin, delineated using global maps at $25,000 \mathrm{~km}^{2}$ resolution) and therefore measures the relative use of water to what is replenished naturally by precipitation and snow melt; ( $v$ ) the band for consumptive surface water use at the study area is shown to be in the medium range, where it is defined as the average annual amount of surface water used in the ecoregion. All these give an indication of both water resources development and of the potential impact of water consumption on freshwater ecosystems. These general-purpose and openly available data show that human developments have concentrated their water use, or where surface water resources are most exploited.

The above general-purpose published indicators correlate well with the local knowledge on the physical reality of the study area now and are an indication of inherent risks within the study area. They show that the future in the study area is faced with unprecedented risks, the exposures for which have been triggered circa 1990. These include (i) the onset of the green revolution in Iran; (ii) an unprecedented dam construction program at the basin of Lake Urmia; (iii) mismanagement of compensation flows and the absence of environmental impact assessment; (iv) the explosion of population, which grew from nearly 40 million in 1980 to nearly 80 million in 2016; and (v) uncontrolled developments, which broke the backbone of traditional agricultural practices and opened the gateways to pumping aquifers and using fertilisers. This is a typical background for the 'tragedy of the commons,' which is created by individuals to maximise their benefit from a shared resource. Normal wells soon depleted aquifers at shallow depths. The practice then changed to using deep-wells to deplete the aquifers even further. Although recently some organisational arrangement have been put in place to cater for abstraction controls under the Iranian Department of Environment, their functions seems to pass on blame to users without putting in place a management system.

Mitigation is only possible by adhering to the UN Sustainable Development Goals through policymaking, risk-based decisionmaking and a set of attributes and principles as discussed by Khatibi (2022). The organisational arrangements for SDGs rely on a professional practice, in which mitigation is implemented by overhauling ad hoc practices on water use and putting in place an appropriate management practice by producing a raft of plans including drought plans, sustainability plan, water cycle management plans and water resources plans.

Climate change mitigation and adaptation is primarily the responsibility of the National Climate Change Office in Iran, under the Department of Environment (which is a governmental agency overseen by the president). Whilst government officials confirm being in favour of sustainable development principles, the authors are not aware of any plans published for the public scrutiny or public attention yet.

\section{Conclusion}

Topical research on Lake Urmia cross-references frequently to climate change, as the cause of its shrinkage. However, climate change is likely to have triggered but not necessarily in full force. The difference between the two cases would affect decisionmakers, as currently they do not invest on restoring the lake by blaming climate change. The paper provides a set of results which show that current problems on precipitation are not necessarily induced by climatic changes but mismanagement the likely cause.

The paper uses LARS-WG and applies to 7 synoptic weather stations within the basin and its overlapping basins at two stages of downscaling and projection. Downscaling by LARS-WG comprises: (i) the use of global-scale GCM models for the prediction of climate variables; and (ii) downscaling them to the local climatic variable using the LARS-WG model in terms of observational data at daily timescale. The study uses the data from synoptic stations in north-west of the country (Ahar, Ardabil, Julfa, Khoy, Parsabad, Tabriz and Urmia) for a period of 40 years (T0: 1961-2001). At the second stage, the LARS-WG model projects its future climate changes under three scenarios (A1B, A2 and B1) for the three 20-year periods. These values are then used to calculate De Martonne Index to delineate the climate zoning by different interpolation methods.

A comparison of observed and downscaled precipitation results indicates that the climates at the studied stations are moving toward drought and the northern region (including Julfa and Parsabad) will be drier and will be developed towards southern

Page $15 / 20$ 
regions. The remaining areas relating to the synoptic stations largely remain within the same climatic band but precipitation

events are likely to be more extreme. The results underpin the need for streamlined water managements as soon as possible, else the damage can become permanent.

\section{Declarations}

\section{Conflict of Interest}

We have no potential conflicts of interest with anyone or any institution.

\section{Funding Statement}

We have obtained no funds for the production of this work.

\section{Author's Contribution}

Rasoul Jani: supervised the research work, produced the initial version, reviewed the finalised paper.

Rahman Khatibi: Critically reviewed the results, rewrote the manuscript, revised its communication.

Sina Sadeghfam: Critically reviewed the modelling results, revised the GIS plots, reviewed the manuscript.

Elnaz Zarrinbal: carried out the modelling activities for her research work.

\section{Availability of data and material}

Our data are available for anyone on request.

\section{Code availability}

We used the standard LARS-WG, hich is available online.

\section{Ethics approval}

We have conducted no laboratory tests for the paper and have involved no Human Participants and/or Animals.

\section{Consent to participate}

The journal has our full consent.

\section{Consent for publication}

The Journal has our full consent to publish our paper and the data.

\section{Consent for Figures}

We have produced all the figure ourselves and need no consent.

\section{References}

1. Abbaspour KC, Faramarzi M, Seyed Ghasemi S, Yang H (2009) Assessing the impact of climate change on water resources in Iran. Water Resour Res 45:1-16. http://doi.org/10.1029/2008WR007615

2. Ahmadijamal M, Hasanlou M (2017) Investigating and modelling effects of climatically and hydrologic indictors on the Urmia lake coastline changes using time series. International Archives of the Photogrammetry, Remote Sensing and 
Spatial Information Sciences, Volume XLII-4/W4, 2017. Tehran's Joint ISPRS Conferences of GI Research, SMPR and EOEC 2017, 7-10 October 2017, Tehran, Iran. https://doi.org/10.5194/isprs-archives-XLII-4-W4-5-2017

3. Ahmadaali J, Barani GA, Qaderi K, Hessari B (2018) Analysis of the Effects of Water Management Strategies and Climate Change on the Environmental and Agricultural Sustainability of Urmia Lake Basin. Iran journal of water 10(2):1-21. http://doi.org/10.3390/w10020160

4. Alborzi A, Mirchi A, Moftakhari H, Mallakpour I, Alian S, Nazemi A, Hassanzadeh E, Mazdiyasni O, Ashraf S, Madani K, Norouzi H, Zarderakhsh M, Mehran A, Sadegh M, Castelletti A, Agha Kouchak A (2018) Climate-informed environmental inflows to revive a drying lake facing meteorological and anthropogenic droughts. Environmental Research Letters 13(8):1-13. http://doi.org/10.1088/1748-9326/aad246

5. Alizade Govarchin Ghale Y, Baykara M, Unal A (2017) Analysis of decadal land cover changes and salinization in Urmia Lake Basin using remote sensing techniques. Nat Hazards Earth Syst Sci Discuss [Preprint]. http://doi.org/10.5194/nhess2017-212

6. Amiri MJ, Eslamian SS (2010) Investigation of climate change in Iran. Journal of Environmental Science and Technology 3:208-216. http://doi.org/10.3923/jest.2010.208.216

7. Azzizzadeh M, Javan K (2018) Temporal and Spatial Distribution of Extreme Precipitation Indices Over the Lake Urmia Basin. Environmental Resources Research 6(1):25-39

8. CarbonBrief (2018) : https://www.carbonbrief.org/mapped-how-every-part-of-the-world-has-warmed-and-could-continue-towarm

9. Delju AH, Ceylan A, Piguet E, Rebetez M (2012) Observed climate variability and change in Urmia Lake Basin, Iran. Theoretical and Applied Climatology 111(1-2). http://doi.org/10.1007/s00704-012-0651-9

10. Ghorbani MA, Khatibi R, Karimi V, Zaher Mundher Y, Zounemat Kermani M (2018) Learning from Multiple Models Using Artificial Intelligence to Improve Model Prediction Accuracies: Application to River Flows. Water Resour Manage 32(4):4201-4215. http:doi.org/10.1007/s11269-018-2038-x

11. Sh HM, Borhani Dariane A (2015) Temperature Trend Analysis in Urmia Lake Basin Compared with Water Level Fluctuations of the Lake. International Conference on Chemical, Civil and Environmental Engineering (CCEE-2015) June 56, 2015 Istanbul (Turkey)

12. Hosseini Moghari SM, Araghinejad S, Tourian MJ, Ebrahimi K, Döll P (2020) Quantifying the impacts of human water use and climate variations on recent drying of Lake Urmia basin: the value of different sets of spaceborne and in situ data for calibrating a global hydrological model. Hydrology Earth and System Sciences 24:1939-1956.

https://doi.org/10.5194/hess-24-1939-2020

13. Jalili Sh, Hamidi S, Morid S, Ghanbar R (2016) Comparative analysis of Lake Urmia and Lake Van water level time series. rabian Journal of Geosciences 9(14):644. http://doi/10.1007/s12517-016-2657-6

14. Khatibi R (in press, Feb. 2022) “Chapter 1: A Basic Framework to Overarch Sustainability, Risk and Reliability - A Critical Review," Risk, Reliability and Sustainability Ed. By Roshni, T., Samui, P., Bui, D., Khatibi, R. and Kim, D., Elsevier Pub

15. Khatibi R, Nadiri AA (2021) Inclusive Multiple Models (IMM) for predicting groundwater levels and treating heterogeneity. Geosci Front 12(2):713-724. http://doi.org/ 10.1016/j.gsf.2020.07.011

16. Khatibi R, Ghorbani MA, Naghshara Sh, Aydin H (2020) A Framework for 'Inclusive Multiple Modelling' with Critical Views on Modelling Practices - Applications to Modelling Water Levels of Caspian Sea and Lakes Urmia and Van. J Hydrol 587(1):124923. http://doi.org/10.1016/j.jhydrol.2020.124923

17. Khatibi R, AA Nadiri (2020) Inclusive Multiple Models (IMM) for predicting groundwater levels and treating heterogeneity. Geosci Front 12(2):713-724. https://iwaponline.com/jh/article/22/6/1640/76755/A-study-of-land-subsidence-problemsby-ALPRIFT-for

18. Parry ML, Canziani OF, Palutikof JP, Linden PJ, Hanson CE (2007) Summary for policymakers. Contribution of Working Group II to the Fourth Assessment Report of the Intergovernmental Panel on Climate Change (IPCC). Adaptation and Vulnerability. Cambridge University Press, UK, pp 7-22

Page $17 / 20$ 
19. Racsko P, Szeidl L, Semenov M (1991) A Serial Approach to Local Stochastic Weather Models. Ecol Model 57:27-41. https://doi.org/10.1016/0304-3800(91)90053-4

20. Razmara P, Massah Bavani AR, Motiee H, Torabi S, Lotfi S (2013) Investigating uncertainty of climate change effect on entering runoff to Urmia Lake Iran. Hydrology Earth and System Sciences 10:2183-2221. http://doi.org/10.5194/hessd10-2183-2013

21. Sadeghfam S, Ehsanitabar A, Khatibi R, Daneshfaraz R (2018) Investigating 'risk' of groundwater drought occurrences by using. reliability analysis 94:170-184. http:// doi.org/10.1016/j.ecolind.2018.06.055

22. Sadeghfam S, Khatibi R, Moradian T, Daneshfaraz R (2021) Statistical downscaling of precipitation using inclusive multiple modelling (IMM) at two levels. Journal of Water and Climate Change 12(7):3373-3387.

https://doi.org/10.2166/wcc.2021.106

23. Sanikhani H, Kisi O, Amirataee B (2018) Impact of climate change on runoff in Lake Urmia basin, Iran. Theoret Appl Climatol 132:491-502. http://doi.org/ 10.1007/s00704-017-2091-z

24. Semenov MA, Brooks RJ, Barrow EM, Richardson CW 1998.Comparison of the WGEN and LARS-WG stochastic weather generators in diver climates.Climate Research, 10:95-107

25. Semenov MA, Brooks RJ (1999) Spatial Interpolation of the LARS-WG Stochastic Weather Generator in Great Britain. Climate Res 11:137-148. https://doi.org/10.3354/cr011137

26. Semenov MA, Barrow EM (2002) LARS-WG a stochastic weather generator for use in climate impact studies. User's manual. Version 3.0.

27. Semenov MA, Stratonovitch $P$ (2010) Use of multi-model ensembles from global climate models for assessment of climate change impacts. Climate Res 41(1):1-14. http://doi.org/10.3354/cr00836

28. Semenov MA, Stratonovitch P Use of multi-model ensembles from global climate models for assessment of climate change impacts.Climate Research

29. Vaheddoost B, Aksoy H (2018) Interaction of groundwater with Lake Urmia in Iran. Hydrol Process 32(21):3283-3295. http://doi.org/10.1002/hyp.13263

30. Zamani Nuri A, Farzaneh MR, Fakhri M, Dokoohaki H, Eslamian S, Khordadi MJ (2013) Assessment of future climate classification on Urmia Lake basin under effect of climate change. Int J Hydrology Science and Technology 3(2):128-140. http://doi.org/ 10.1504/IJHST.2013.057625

\section{Figures}

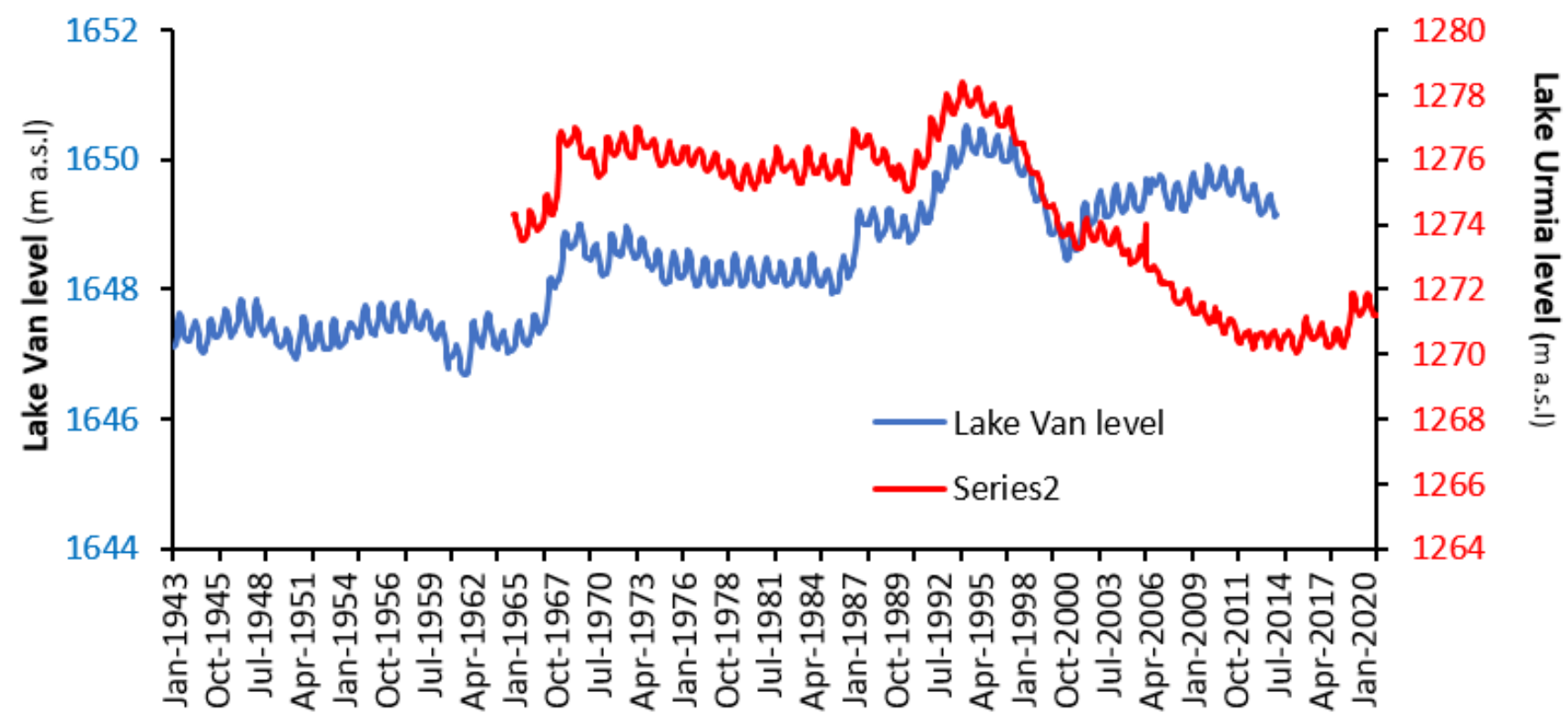

Page $18 / 20$ 
Figure 1

Intercomparison of lake water levels between Lake Urmia and Lake Van

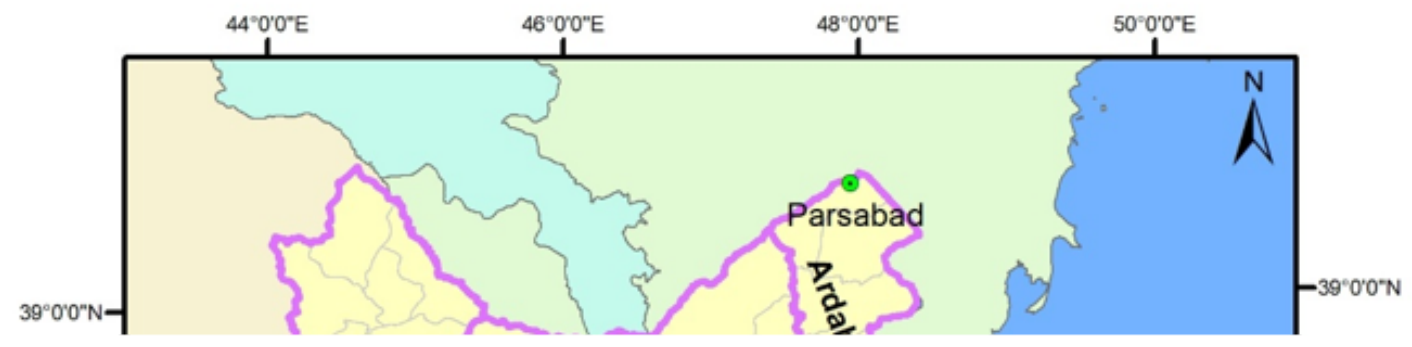

\section{Figure 2}

The location map and investigated synoptic stations

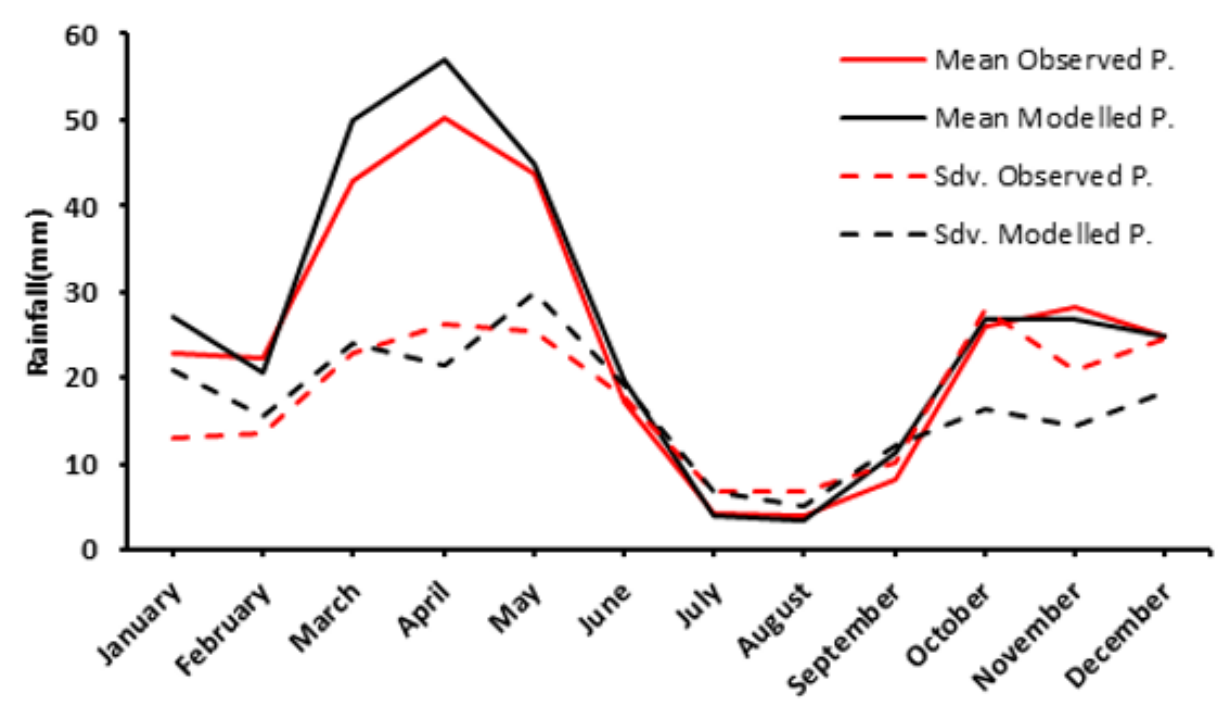

Figure 3

Comparing observed and modelled precipitation in Tabriz station (T0: 1961-2001) 


\section{Figure 4}

Mean Precipitation for each month for T0, T1, T2 and T3 periods at each station for each scenarios

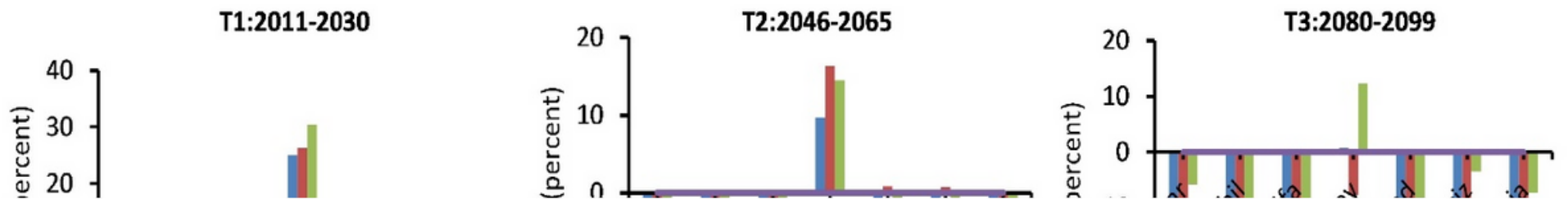

\section{Figure 5}

Percentage of change in total annual precipitation at each station, each scenario and at T1, T2, T3

\section{Figure 6}

Zoning map for the study area under Scenarios: A1B, A2 and B1 for T1, T2 and T3 Periods 